\title{
The Moment of Communion
}

\author{
Lee Palmer Wandel
}

The Siebenhirter Hours, dated shortly before $1469,{ }^{1}$ contains a singular image, painted by the Lehrbüchermeister, of the very moment when communicants receive the host [Fig. 7.1]. While images of the Mass of Pope Gregory, by far the most studied of images of Communion, centre on the priest and the doctrine of transubstantiation, ${ }^{2}$ this one centres on the recipient and the moment when the host enters the mouth. ${ }^{3}$ Images of the Mass of Pope Gregory centre on the pope, and hold forth his experience as at once a miracle and the ideal. ${ }^{4}$ This image renders diversity of experience among lay recipients. It invites us

1 Stockholm, Kungliga Biblioteket, MS A 225, fol. 158v. I am very grateful to Aden Kumler, who showed this image in the Corinth Colloquium, "Quid est sacramentum?" For her interpretation of that image, see "Counterfeiting the Eucharist in Late Medieval Life and Art", in Melion W.S. - Pastan E. - Wandel L.P. (eds.), Quid est sacramentum? Visual Representation of Sacred Mysteries in Early Modern Europe, 1400-1700 (Leiden - Boston: 2019) 57-81.

2 The research group, Kulturgeschichte und Theologie des Bildes im Christentum, at the Westfälische Wilhelms-Universität Münster produced a databank of images of the Mass of Pope Gregory: https://gregorsmesse.uni-muenster.de.

3 This article builds on my previous work, foremost as published in The Eucharist in the Reformation: Incarnation and Liturgy (New York - Cambridge: 2006). Please refer to its bibliography for scholarship on the practice and theology of the Eucharist. In attending to the moment of reception - as critically distinct from the moment of consecration - this essay moves away from almost all scholarship on the sacrament. While there are substantive bodies of work on the Mass, on the doctrines of transubstantiation and real presence, and on the elevation of the host, Caroline Walker Bynum's Holy Feast and Holy Fast: The Religious Significance of Food to Medieval Women (Berkeley, CA: 1987) remains in many ways singular, in particular in its attention to the experience of reception. On the Mass, see foremost Jungmann J., Missarum Sollemnia: Eine genetische Erklärung der Römischen Messe, 2 vols. (Freiburg: 1962). For an introduction to Reformation debates on transubstantiation and real presence, see Wandel L.P. (ed.) A Companion to the Eucharist in the Reformation (Leiden Boston: 2014), Part I; and Wandel L.P., The Eucharist in the Reformation. In contradistinction to the doctrines of transubstantiation and real presence, there is very little on the question of worthiness and nothing on its import for the substance of the elements.

4 On the Mass of Pope Gregory, see foremost Bynum C.W., "Seeing and Seeing Beyond: The Mass of St. Gregory in the Fifteenth Century", in Hamburger J. - Bouché A.-M. (eds.), The Mind's Eye: Art and Theological Argument in the Middle Ages (Princeton, NJ: 2006) 208-240; Meier E., Die Gregorsmesse: Funktion eines spätmittelalterlichen Bildtypus (Cologne: 2006); Gormans A. - Lentes T. (eds.), Das Bild der Erscheinung: Die Gregorsmesse im Mittelalter (Berlin: 2007).

(C) LEE PALMER WANDEL, 2022 | DOI:10.1163/9789004153073_008

This is an open access chapter distributed under the terms of the CC BY-NC-ND 4e license. wandel - 9789004153073 


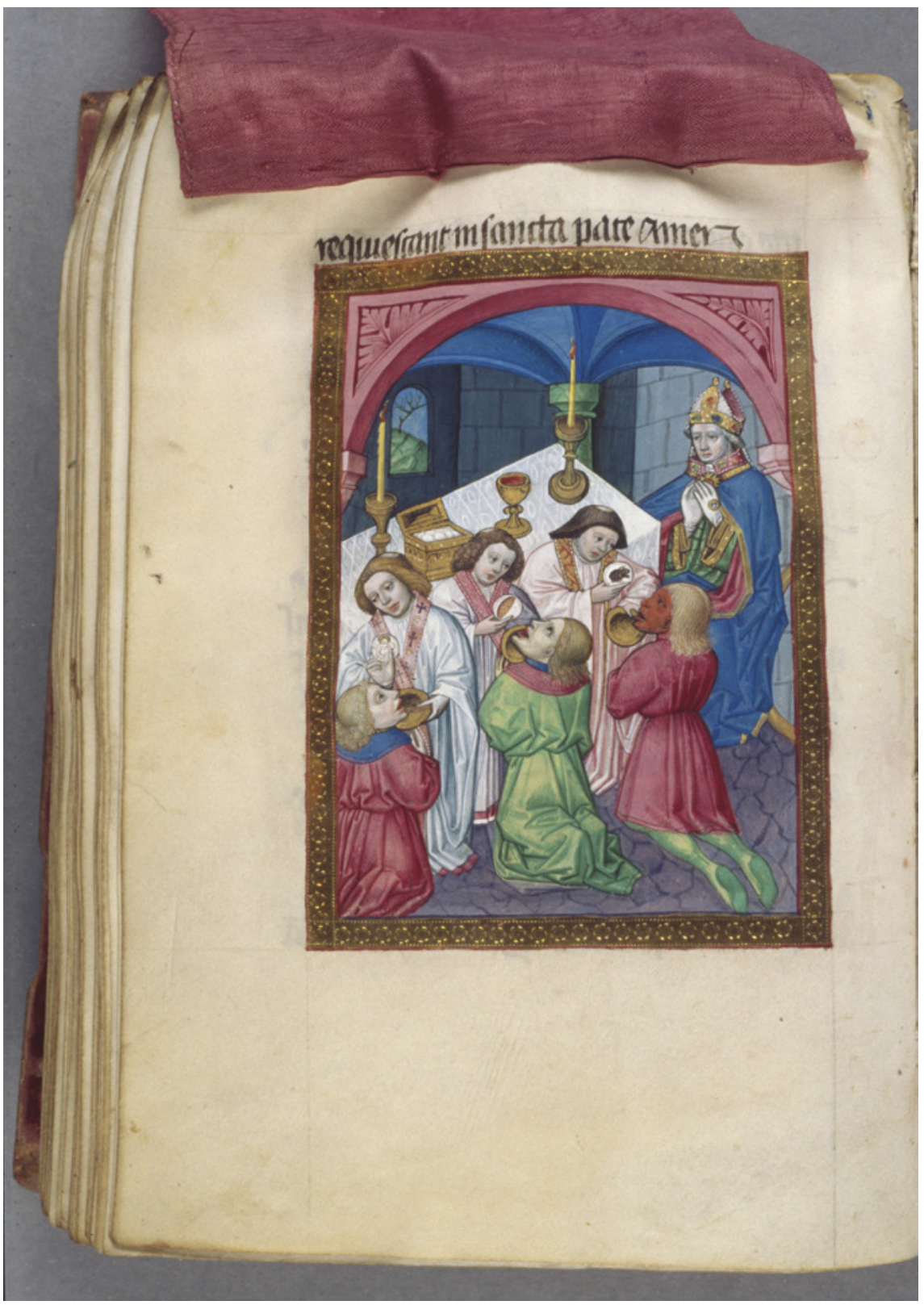

FIGURE 7.1 Lehrbüchermeister, Siebenhirter Hours [approx. 1470] NATIONAL LIBRARY OF SWEDEN, MS A 225 
to meditate not on the moment of consecration but on the moment of reception, a moment which in turn invites us to reflect on 'privacy' in the terms set forth in Mette Birkedal Bruun's "Work Method", specifically, 'zone', 'person', and 'threshold'. Finally, in representing the moment of Communion as variable, the Siebenhirter Hours image both underlines the radical instability of the matter of the host and calls the viewer's attention to the recipient as equally essential to the moment. The image thus points to the question of 'worthiness', set forth in 1 Corinthians 11:

Whoever, therefore, eats the bread or drinks the cup of the Lord in an unworthy manner will be answerable for the body and blood of the Lord. Examine yourselves, and only then eat of the bread and drink of the cup. For all who eat and drink without discerning the body, eat and drink judgment against themselves. ${ }^{5}$

As it became so very clear in the sixteenth century, 'worthiness' was not necessarily visible. To shift to the terms of this volume, it was and is not 'public'. Does that make 'worthiness' something 'private' - given the common opposition in contemporary thought - or does the moment of Communion contain within it multiple zones, some public, some less so, and posit a notion of 'person' of multiple layers of knowability? Before seeking to answer this question, let me sketch in brief the moment of Communion in terms of zone, person, and threshold first as represented in a late medieval manuscript illumination and then as reconceived in the sixteenth century. This sketch draws on my earlier work; footnotes point towards rich literatures on each aspect I must necessarily so very quickly traverse.

\section{The Spaces of Communion}

The Siebenhirter Hours image renders that which would have been important to receiving the sacrament of Communion. Late medieval Christians could receive it in a private chapel, a chapel within a church, a parish church, a cathedral, or a basilica. Technically, Communion could take place anywhere: the medieval Church allowed the administration of the sacrament in times of exigency, whether the home of the dying or the battlefield. It did not require the walls of a church or chapel or an altar. But, as the image suggests, the

51 Corinthians 11:27-29, Coogan M. (ed.), The New Oxford Annotated Bible, 3rd ed. (Oxford: 2001). 
sacrament was offered normally and normatively within the walls of a church, at an altar. The spaces of Communion were, as the image renders, multiple and nested: at an altar within a church of some kind. Thinking of those spaces as zones, nested one in the next, let us move from the walls of a church to the mouth of the recipient.

As the image visualises, with its windows and their glimpse of green and trees, the space of Communion was demarcated by walls. ${ }^{6}$ Those walls marked a boundary between the interior of each church - be it wayside chapel or parish church or cathedral - and the exterior. The walls also demarcated a boundary between a space that had been consecrated to worship, the interior, and what, in direct contrast, was construed as the 'secular' or 'mundane'. Each church, before it might be used for worship, was, following Pontificals, to be consecrated by a bishop, through a formal rite which itself was public, involving a range of persons. The walls were porous: mundane practices occurred within them. But they marked a space within which the sacraments were to be celebrated.

Last Rites normally were administered within a home; the sacrament of marriage, at the threshold of a church. ${ }^{7}$ The other sacraments - baptism, confirmation, confession and penance, and ordination - occurred within the consecrated space of a church. The largest zone for Communion was a space not only of sacraments, but of sacred acts that defined the stages of the Christian life [Fig. 7.2].

The walls were permeable; secular practices occurred within them. More critically to a conceptualisation of the walls, bells communicated far beyond them the liturgical structuring of all time for medieval Europeans, Christian or not, sonically extending the space of worship far beyond the material walls. Bells rang the different kinds of Christian time: the hours of the Divine Office matins, lauds, prime, terce, sext, none, vespers, and compline; feast days of the Christian year, the Temporale, Sanctorale, and Marian cycles of time; the time of Mass; the moment of the elevation of the host and chalice. Within the zone of the church was the structuring of time in Christian Europe, both collective time and the intimate experience of divine presence. Thus, the first zone of Communion was both permeable and itself the site of sound that

6 For an excellent introduction to the relationship between liturgy and architecture, see Van der Ploeg K., Art, Architecture, and Liturgy: Siena Cathedral in the Middle Ages (Groningen: 1993) Introduction. For a close study of a single church and its multiple liturgical uses, see especially Nickson T., Toledo Cathedral: Building Histories in Medieval Castile (University Park, PA: 2015) esp. Part 3.

7 Roper L., "'Going to Church and Street': Weddings in Reformation Augsburg", Past \& Present $106(1985) 62-101$. 


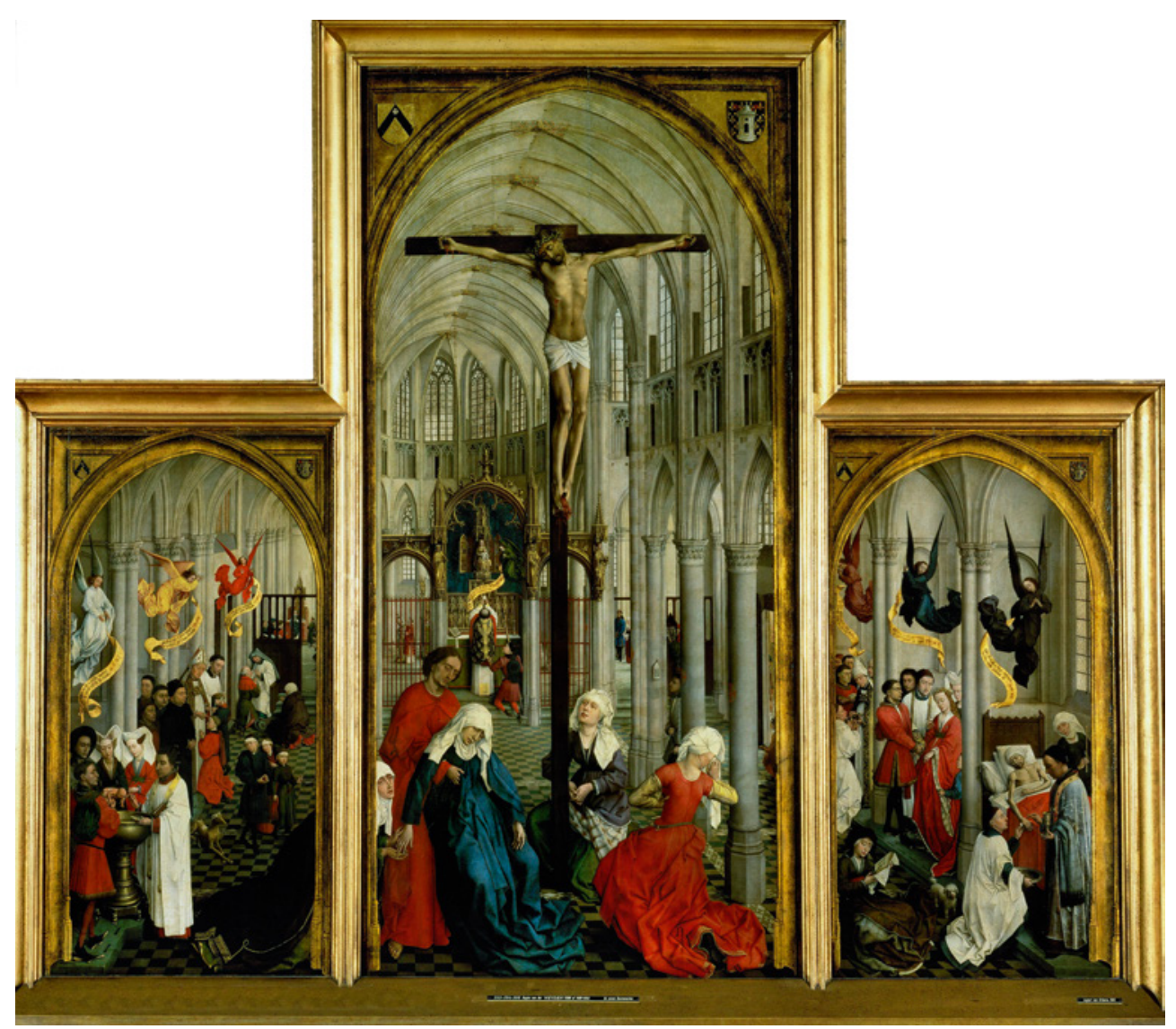

FIGURE 7.2 Rogier van der Weyden, "Altar of the Seven Sacraments" (before 1450), painting KONINKLIJK MUSEUM VOOR SCHONE KUNSTEN, ANTWERP, BELGIUM. ERICH LESSING / ART RESOURCE, NY

extended it perceptibly, blurring any clear demarcation of secular and sacred, mundane and consecrated.

Within the walls was a visually complex world, which we can see in the Van der Weyden, of choir screens, retables, crucifixes, sculpture, a density of many different kinds and sizes of images. Jacqueline Jung has detailed the multiple visual and devotional work of choir screens in chapters treating them as partition, bridge, and frame. ${ }^{8}$ Reindert Falkenburg has suggested that retables

8 Jung J., The Gothic Screen: Space, Sculpture, and Community in the Cathedrals of France and Germany, ca. 1200-1400 (Cambridge - New York: 2013) Part I. 
could evoke the breaking of the host at Communion. ${ }^{9}$ The images are material traces that, among other things, remind us of individual imaginations and their role in the reception of Communion.

So, too, to this largest zone belongs the practice of catechesis, which Reformation Churches all came to practise. Medieval Christians may or may not have received catechesis, but the learning of words that would then be spoken in the Mass - the Apostles' Creed and the Lord's Prayer - also occurred in this space, binding person to person in the shared cadences of the words of the simplest of Christian lives. ${ }^{10}$ These words within this space might be said to have formed one of the 'publics' before whom communicants received Communion.

The time of the Mass might be said to create a second zone. The celebration of the Mass did not simply occur within the walls of a church, but was the reason for its consecration. The space and the celebration of the Mass were deeply and complexly interdependent. The Mass could be celebrated outside a church, and mundane activities could occur inside the walls of a church, but, as many images suggest, the church was the space of the Mass.

Different scholars have divided the temporal structure of the Mass in different ways: Arthur Young divided it into five movements: the preparation, the oblation, the consecration, the communion, and the dismissal. ${ }^{11}$ Joseph Jungmann divided 'the Sacrifice', or the Mass of the Catechumens, from all that came before, from the priest's preparations through the service of readings to the Credo. ${ }^{12}$ Thus, the second zone, of the Mass, was both spatial and temporal. Equally, the learned words of the Credo and the Lord's Prayer were to be spoken within the temporality of the Mass or, later, with the fragmentation of the Reformation, the Lord's Supper, moments of integration of person and sacred rhythms.

Within the walls, during the Mass, sound encompassed the space, creating aurally a communal place. The Ordinary - the Kyrie, the Gloria, the Credo, the Sanctus, the Agnus Dei, and the dismissal - was constant from Mass to Mass, the words sung by choirs in larger churches, chanted by priests in smaller. The Proper - the Introit, the Gradual, the Alleluia, the Offertory, and the Communion chant - differentiated each Mass according to the liturgical calendar, but the two were interwoven in the cadence of the Mass, the one constant, the other marking different kinds of sacred time. Devout laity

Falkenburg R., "Hieronymus Bosch's Mass of St. Gregory and 'sacramental vision', in Gormans - Lentes (eds.), Das Bild der Erscheinung 179-206.

10 Wandel L.P., Reading Catechisms, Teaching Religion (Leiden - Boston: 2016).

11 Young K., The Drama of the Medieval Church, vol. 1 (Oxford: 1933) 19.

12 Jungmann, Missarum Sollemnia. 
participated in the creation of shared sound, speaking the Credo, the Lord's Prayer, shared prayers, Amens.

So, too, the Siebenhirter Hours image renders the next, nested zone for receiving the sacrament. Partially obscured by the figures before it, the altar designated by the starkly white corporal as well as the pyx and the chalice upon it - is the single largest object in the image. The illumination stipulates neither the size of the church nor whether the altar was one of many; it depicts walls and altar. In this, too, the image, in not specifying a place or a particular altar, points toward that which was normative and normal: late medieval Christians could receive communion at an altar in a chapel, a side altar in a church, at the high altar of a cathedral. An altar was critical, albeit not essential, to Communion, but no one altar, no one kind, no one placement - in chapel or choir, cathedral or roadside shrine - was. If a church was the space within which the Mass was celebrated, the altar was the site of the Mass.

Altars, more and more often built out of stone, were a constant presence within the walls of a church. ${ }^{13}$ Like the space within which they had been placed, altars were consecrated, ${ }^{14}$ like that space, they remained, even when no Mass was being celebrated, a material presence. Altars were never mere surface. By the time this image was executed, altars had come to contain relics, hidden from sight but known to be present.

Pontificals contain discrete rites of consecration that the medieval and Tridentine Church formally required: for altars, for vestments, for liturgical vessels, as well as for the space of the church. Each of those acts of consecration was not only formal, its words and gestures scripted in the codex, but also public, done in front of others attending. The white object in the Siebenhirter Hours image would have thus been read, given what was depicted as happening before it, as consecrated to be the site for the celebration of the Mass.

Before turning to persons and thresholds, let me quickly sketch the many changes Reformation instituted to the spaces of Communion outlined here. In all places where Evangelicals instituted Reformation, they silenced the cadences and the bells of the Divine Office. Perhaps more critically, Lutherans, Reformed Christians, Anabaptists, Mennonites - most Evangelicals - rejected sacerdotal power, both the sacrament of ordination and the specific authority that sacrament conferred on the men who received it. Thus, while Lutherans

13 For this and following, see foremost Braun J., Der christliche Altar in seiner geschichtlichen Entwicklung, 2 vols. (Munich: 1924).

14 As Durand notes, not only the church, but also the altar was to be consecrated, book I, ch. 7, paragraph 1, Durand William, Gvillelmi Dvranti Rationale Divinorvm Officiorvm I-IV, ed. A. Davril - T. Thibodeau (Turnhout: 1995) 84. 
might continue to consecrate their churches to worship, that consecration was no longer spoken by an ordained priest.

The place of communion had been from the beginning and remained throughout the Reformation 'public' in certain ways: from the earliest conventicles to the Churches of the Reformation, Christians gathered together for Communion. If in the earliest years of persecution, Christians might gather clandestinely, from the time of Constantine forward, Christians gathered in spaces open to all Christians, though they be strangers to one another. They gathered in spaces that, over generations, had become more complexly 'public', if one might push the term, spaces which encompassed the graves and remains of donors, bishops, holy persons; images of Mary, apostles, saints. During the Reformation, iconoclasts might strip those spaces of the material remains of donors, Mary, apostles, and other saints - of their relics as well as the matter that had been made to honour them - thus reducing the 'public' of Communion, ${ }^{15}$ but for all Christians, the church building remained a space open to members of their confessionally defined Church.

Lutherans preserved altars, but used only one, in the nave, as the site of Communion. ${ }^{16}$ Huldrych Zwingli and John Calvin called for tables to replace altars. Neither church nor table were to be consecrated in Zurich or Geneva or the places that looked to them for leadership, neither was considered holy. Churches in these places were spaces for worship, undifferentiated by degrees of consecration or degrees of holiness. For all European Christians, the walls depicted in the Siebenhirter Hours image remained constant, marking a (permeable) boundary, within which Christians gathered to receive Communion. They no longer agreed on the presence of that which is marked by brilliant white cloth, and they divided bitterly over the exact nature of the power of the four figures distinguished by vestments, and in particular, the figure on the right side of the image, to whom we now turn.

The image visualises, dramatically, the 'zone' of the space of host and mouth and the mouth as a threshold to the person. Before taking up the host, the mouth, and the person of the recipient, we turn to the Siebenhirter Hours image's visual articulation of persons.

15 Wandel L.P., Voracious Idols and Violent Hands: Iconoclasm in Reformation Zurich, Strasbourg, and Basel (Cambridge - New York: 1995).

16 On Lutheran Churches and their liturgies, see Spicer A. (ed.), Lutheran Churches in Early Modern Europe (Abingdon - New York: 2012). 


\section{2 \\ Person}

The Siebenhirter Hours image depicts a total of seven figures, three pairs in front of the altar and one figure placed to its side. Four of the figures are distinguished by vestments, which, as William Durand wrote, signalled layers of sacerdotal authority:

there are six things which commonly belong to all priests, namely: to catechise, baptise, preach, consecrate [conficere] [the elements], loosen and bind. But there are nine things that specifically belong to the [bishop], namely: to ordain clerics, bless consecrated virgins, consecrate other bishops, lay on hands, dedicate basilicas, depose those who have been removed from orders, celebrate synods, make the chrism, and consecrate the liturgical vestments and vessels. ${ }^{17}$

Vestments distinguish from all the others the one figure placed to the right of both the altar and the scene, who holds his gloved and jewelled hands in a gesture of prayer. Those vestments - the mitre, cope, and palium - designate him as a bishop. ${ }^{18}$ The vestments thus mark that figure as fundamental to what is taking place in the image, even as the Lehrbüchermeister placed him on the edge of the image. His vestments mark him as authorised to ordain priests who, once ordained, could effect the transubstantiation of the elements, following the decree of the Fourth Lateran Council:

Nobody can effect this sacrament except a priest who has been properly ordained according to the Church's keys, which Jesus Christ himself gave the apostles and their successors. ${ }^{19}$

17 Rationale divinorum officiorum, book II, ch. 11, paragraph 13, William Durand: On the Clergy and Their Vestments, trans. T. Thibodeau (Chicago: 2010) 127; II, XI, 13: 'Differt autem inter episcopos et sacerdotes, quia licet sex sint que communiter ad omnes pertinent sacerdotes: uidelicet cathecizare, baptizare, predicare, conficere, soluere, ac ligare; tamen ad pontificem nouem specialiter spectant: scilicet clericos ordinare, uirgines benedicere, pontifices consecrare, manus imponere, basilicas dedicare, degradandos deponere, synodos celebrare, crisma conficere, uestes et uasa sacrare', Gvillelmi Dvranti Rationale Divinorvm Officiorvm I-IV 175 .

18 Book III, ch. 8, paragraph 1, Gvillelmi Dvranti Rationale Divinorvm Officiorvm I-IV 197.

19 'Et hoc utique sacramentum nemo potest conficere, nisi sacerdos, qui fuerit rite ordinatus secundum claves ecclesiae, quas ipse concessit apostolis et eorum successoribus Iesus Christus' Decrees of the Ecumenical Councils, ed. N.P. Tanner, S.J., vol. 1 (London Georgetown: 1990) 230. 
Necessary in the medieval Church for the moment of Communion is the person of the priest: a man who had received the sacrament of orders, whose clothes marked him as having received that sacrament and in so doing, having been transformed, his very nature altered. ${ }^{20}$ In the miniature, the vestments of the figure of the bishop invoke the sacrament of orders, the sacerdotal power conferred through that sacrament. In distinguishing him not only from the laity, but also from those assisting in Communion, his vestments also mark him as the sole figure who could have consecrated the elements.

The three figures standing before the altar are also distinguished by vestments: the alb and the stole. ${ }^{21}$ The absence of the chasuble suggests that these three figures are not officiating in this Mass, but assisting the bishop. They do not have the same authority, nor the sacerdotal power of the bishop. The vestments thus manifest a hierarchy of clerical power. They also point towards an otherwise unrepresented sequence: prior to the moment represented in the image, the bishop has celebrated all but the benediction and dismissal of the Mass and has already consecrated both host and wine. Depicted is a moment that follows consecration: assistants offer hosts to communicants. ${ }^{22}$

Following Durand, the vestments were not simply marks of sacerdotal office. They were also to manifest virtues, such as humility, and a way of life, encompassing charity and celibacy. They thus both designate and manifest, an office and a person who has been transformed through the sacrament of ordination. The vestments invite the viewer to consider one play of virtue and visualisation. The central drama invites the consideration of another.

The Lutheran, Reformed, Anabaptist, and Mennonite Churches instituted in the sixteenth century rejected both the sacrament of ordination and the vestments that had visualised that sacrament and its transformation of the person receiving it. In 1524, in Zurich, in a gesture demonstrating this radical rejection of sacerdotal power and its marks, vestments were handed out to the poor, ${ }^{23}$ reduced to mere clothing, something which could cover the poorest in their need. In Geneva as in Wittenberg and Zurich, those now called ministers administered the sacrament of Communion. ${ }^{24}$ So, too, Martin Luther, Zwingli, Calvin, Anabaptist, and Mennonite theologians all rejected Fourth

20 For an introduction to the sacrament of ordination, see Bradshaw P.F., Rites of Ordination: Their History and Theology (Collegeville, MN: 2013).

21 On vestments, in addition to Durand, see Miller M.C., Clothing the Clergy: Virtue and Power in Medieval Europe, c. 800-1200 (Ithaca - London: 2014); Wandel L.P., "Vestments in the Mass", in Quid est sacramentum? 82-104.

22 On the sequence of the Mass, see foremost Jungmann, Missarum Sollemnia.

23 Wandel, Voracious Idols and Violent Hands 97.

24 On the changing role of the celebrant, see Wandel, The Eucharist in the Reformation. 
Lateran's formulation of the power of the priest and that any human being could effect the transformation of the elements into the body and blood of Christ. Ministers of these Churches could not effect it, and their clothing, the robes of a doctor of Scripture, signalled a very different kind of authority, rooted not in a sacrament, but in knowledge of the sacred text that itself possessed supreme authority.

The vestments in the Siebenhirter Hours image signal a power that the Council of Trent would affirm, ${ }^{25}$ and separate four figures from the three recipients. Those three wear tunics of varying lengths, alternating left to right in the image, red, green, and red. Untonsured and unmarked by any clerical sign, they can be read as laity. Equally significant, their clothing connects each, through the jewel-like red, green, and blue, to the figure of the bishop. The leftmost two wear longer tunics, while the figure on the right is the only figure whose feet are visible and who wears leggings.

While Evangelical Churches rejected vestments and the power they signalled, these three lay figures represent an anxiety which all Churches shared and which intensified in the fragmentation of the Reformation. The three are differentiated in the colouring of their faces as well as in the objects that the three clergy offer, to which we turn below. Most striking of the three is the figure on the right, closest to the bishop, whose face is a different shade of red from his tunic, but whose face separates him from all the other figures in the image. That red face can be construed in many ways ${ }^{26}$ - each of which deny to that person the proper state of piety to receive Christ's presence in the host.

\section{3}

\section{Threshold and Matter}

The Lehrbüchermeister chose to render the mouths of all seven figures in red, the same red as the two tunics. Those mouths are the dramatic centre of this image. To take up the terms of the "Working Method", they suggest a threshold. Indeed, it is only in construing the mouths as a threshold that we can discern the terrifying significance of what the three clergy hold before those mouths.

Immediately preceding the moment of communion, within the cadence of the Mass, were the words of institution. ${ }^{27}$ Immediately following the words,

25 Session 23, 15 July 1563, Decrees of the Ecumenical Councils, vol. 2, 742-744.

26 See, for example, Mellinkoff R., Outcasts: Signs of Otherness in Northern European Art of the Late Middle Ages, vol. 1 (Berkeley: 1993) ch. 7; and Lipton, S., Dark Mirror: The Medieval Origins of Anti-Jewish Iconography (New York: 2014) ch. 5 .

27 The following draws foremost on Jungmann. See also Wandel, The Eucharist in the Reformation ch. 1. 


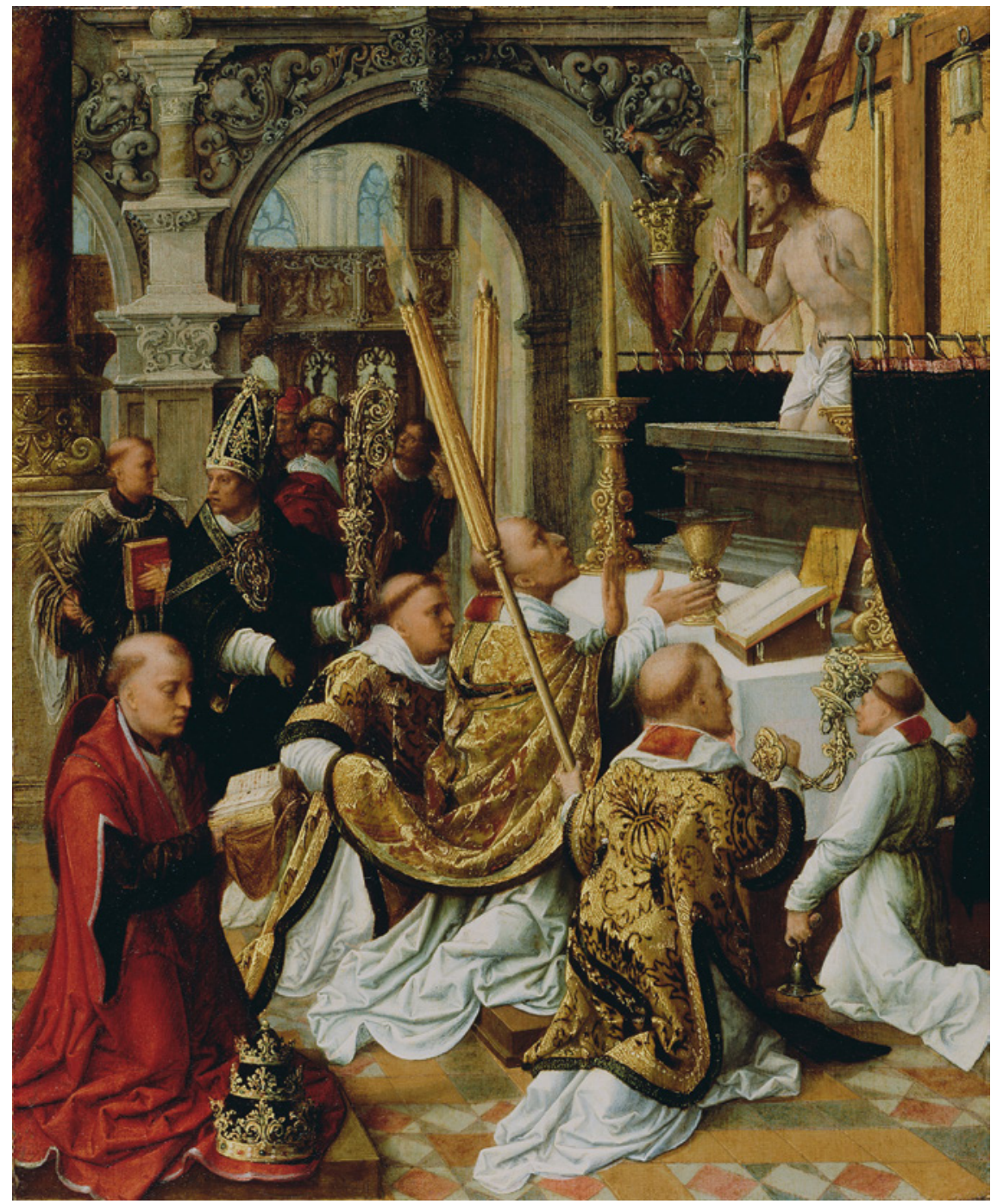

FIGURE 7.3 Adriaen Isenbrandt, "The Mass of Saint Gregory the Great" (c. 1510-1550), painting, $362 \mathrm{~mm} \times 292 \mathrm{~mm}$

J. PAUl GETTY MUSEUM

'Hoc est enim Corpus meum', the celebrant elevated the host, and then, following 'Hoc est enim Calix Sanguinis mei, novi et aeterni testamenti, mysterium fidei, qui pro vobis et pro multis effundetur in remissionem peccatorum', the chalice, each elevation marked aurally by the ringing of bells. ${ }^{28}$ Communion

28 The Saint Joseph Daily Missal (New York: 1950) offers the following translation of these words: 'For this is my Body. [...] For this is the Chalice of my Blood of the new and eternal 
was the culmination of stages of preparation, from the priest's ablutions that occurred outside of the laity's sight, through the prayers and gifts, to the Sanctus, sung or chanted, by priest alone or priest and choir. The moment of Communion occurred near the end of the Mass in its entirety, when the congregation and the clergy had 'moved' towards the singularly dramatic moment of transubstantiation. It occurred within, as Jungmann's division suggests, a more intensive sequence of preparation. Between consecration and lay communion, the laity first heard the priest's prayers, then themselves collectively recited the Lord's Prayer, then heard prayers at the commingling of the elements, collectively recited the Agnus dei, exchanged the kiss of peace, heard the prayers at the communion of the celebrant. Only then did the laity approach, move to the altar, where each received Communion individually. Final prayers and the dismissal to return 'to the world' occurred after all who had approached the altar received the host.

To the point of Communion, and afterwards, the ritual of the Mass was both public and communal, a shared preparation for a singular moment of sacred presence (or absence). The Mass was celebrated in a space in which high stone walls pierced by windows delimited an inside from an outside, a place distinguished from the world by the act of consecration. The vestments symbolised a hierarchical authority which governed the space and the sacraments. Even as the Mass might be, on high feast days, celebrated in the choir or apse, quite possibly separated from the nave by a choir screen or rood screen, when the laity were invited to take Communion, they shared the same space.

In the midst of a complexly constructed shared movement within a shared space, each Christian received Communion individually. That reception is the subject of the Siebenhirter Hours image. Unlike images of the Mass of Pope Gregory, in which the central drama occurs at the altar, between the celebrant and the person of Christ, in the Siebenhirter Hours, the drama centres on three red mouths and what can be seen on each of three patens, between the assistant and the recipient. The visual argument is neither for real presence nor for sacerdotal power to invoke that presence.

The mouths of the recipients have been rendered in bright red, calling attention to the mouth as the point of entry into, the threshold of, their bodies.

covenant; the mystery of faith, which shall be shed for you and for many unto the forgiveness of sins' 566. As Jungmann notes, the texts of the words of institution were never simply the restatement of a scriptural text, Missarum Sollemnia II, 243-244. In the sixteenth century, as Evangelicals formulated liturgies that broke with medieval practice in many different ways, those formulae also altered the words of institution, according to their divergent understandings of just what happened at the Seder the night before Jesus was crucified. On the divergent formulae, see Wandel, The Eucharist in the Reformation. 
What each of the three assistants holds out makes the visual argument that Communion was not the same for all. All three are white and circular - evoking the host of so many images of Communion. But on those three white circles are three significantly different objects: reading left to right, an image of the infant Jesus with halo, a piece of bread, and a toad. ${ }^{29}$

The Siebenhirter Hours image is poised just before communicants receive the host in their mouths. Accounts of mystics take us into the moment of Communion, the moment immediately following the one in the illumination, in which the host has crossed the lips. Two from Caroline Walker Bynum's Holy Feast and Holy Fast suggest the blurring of boundaries of person and matter that, in turn, enables us to understand more fully the terrifying significance of those three hosts.

Ida of Louvain (d. ca. 1300) desired frequent communion, but, according to Bynum, 'was too modest [...] to receive the eucharist without [her confessor's] permission'. Her communion, as set forth by her hagiographer, reminds us how problematic is any ready separation of matter and presence:

It frequently happened at that time that, when the priest received the holy communion at the altar, as the custom was, she, in the intensity of her desire, received with her mouth at the selfsame moment the most sacred pledge of the host of the Savior (brought, we believe, by a ministering angel) and discerned it with the sense of taste and even chewed it with her teeth. ${ }^{30}$

Angela of Foligno (d. 1309) differentiated among her own moments of communion:

She said that sometimes, when she made communion, the host expanded in her mouth and she tasted neither bread nor the meat which we know. Certainly it had the savor of meat but with a completely different taste, which 'I do not know how to compare to anything else in this world'. It went down with great ease and sweetness and not with the difficulty to which she was accustomed. She said that it softened quickly and was not hard as it usually was. And it had such sweetness that 'had I not heard it

29 For an introduction to medieval debates on the matter of the host, see Levy I.C. - Macy G. Van Ausdall K. (eds.), A Companion to the Eucharist in the Middle Ages (Leiden - Boston: 2012). For an introduction to Reformation debates, see Wandel (ed.), A Companion to the Eucharist in the Reformation Part I. 
said that a person ought to swallow quickly I would have held it freely in my mouth with great delay. But at such times I remember suddenly that I ought to swallow quickly, and the body of Christ goes down whole with that savor of unknown meat, nor do I need to drink anything afterwards. But this does not normally happen and so I make a great effort that no crumb of the host remains between my teeth. But when it does descend in this way, it gives me a great feeling of peace. And this is discerned outwardly in my body, because it makes me tremble violently, so that only with great effort am I able to grasp the chalice. ${ }^{31}$

In these accounts, the moment of Communion confounds distinctions of body, matter, object, divine presence. The priest, whose presence was doctrinally essential to the moment of Communion, becomes an avatar in the account of Ida's Eucharistic devotions, at best, marking the moment with his own Communion, but physically and sacramentally separate from the angelic Communion offered to Ida. Angela's intense focus on the physical experience of the host excludes space, sound, priest, even the chalice.

The Siebenhirter Hours miniature represents the moment of Communion not as encompassing the necessary presence of Christ - the assumption that informed both mystics' accounts - but as essentially vulnerable. It renders not simply different experiences - the host with Christ and the host with a piece of bread - but antithetical ones: the host with the toad is visually opposite, in placement and in colouring, to the host with the image of Christ. ${ }^{32}$ If the mystics in Bynum's study experienced the real presence of Christ, the Siebenhirter Hours image suggests that that presence was not constant for all: only one host of the three has an image of Christ on it.

The image visualises that the words of consecration alone could not ensure the presence of Christ. The red face of the recipient of the host with toad is one visual cue: this figure differs from all others in the image, and that red face is proximate to the toad. In the visual argument of the image, Christ was not always present in the host, but present only for a few. For the others, Christ might be absent (the bread) or indeed, damnation might be present (the toad). The difference, as the Siebenhirter Hours image renders so clearly, was not only one of hosts, but also of recipients.

31 Bynum, Holy Feast and Holy Fast 141-142.

32 For one reading of the toad, see Hamburger J., "Bosch's 'Conjuror': An Attack on Magic and Sacramental Heresy", Simiolus: Netherlands Quarterly for the History of Art 14.1 (1984) $4^{-23}$. 
The matter of the host, in other words, was not stable. Consecration did not ensure the presence of Christ with every host. The matter of the host depended on the person receiving. The image visualises the terror of Paul's admonition to the Corinthians: the danger of communicating unworthily. As those different hosts entered the red outlined mouths, they did not remain discrete from the bodies that received them.

This sense of the moment of Communion, the anxiety not about the host, but about the recipient and the consequences of communicating without proper preparation, is a recurrent theme in Book IV of the Imitatio Christi, here at Chapter 6, in which The Disciple says,

Lord, when I consider Your dignity and my own wretchedness, I am full of fear and confusion. For if I do not receive You, I refuse life; and if I intrude myself unworthily, I incur your displeasure. ${ }^{33}$

Or in Chapter 12, when Christ says,

However, know that even your best efforts cannot make a worthy preparation for Me, although you were to prepare for a whole year and do nothing else beside. ${ }^{34}$

The preparation of the Imitatio encompassed self-examination and prayer. A number of those prayers spoke directly to the anxiety that no preparation was sufficient. 'What can I do', the Disciple asks, 'to atone for my sins, but humbly confess and lament them, and constantly implore your propitiation?'35

Reformation Churches changed so very much of the practice of Communion, from the rejection of the sacrament of ordination through divergent conceptualisations of the real presence. And yet, all taught Paul's warning. They differed again on what 'worthiness' encompassed. For Peter Canisius, following Aquinas, 'worthiness' encompassed the sacrament of penance. ${ }^{36}$ Luther's

33 Á Kempis Thomas, The Imitation of Christ, trans. L. Sherley-Price (Hammondsworth: 1952) book IV, ch. 6, 196. 'Si enim non accedo, vitam fugio; et si indigne me ingessero: offensam incurro' Á Kempis Thomas, The Imitation of Christ; De imitatione Christi, ed. P.A. Böer (Middleton, DE: 2014) 571.

34 Á Kempis, The Imitation of Christ, book IV, ch. 12, 207. 'Scito tamen te non posse satisfacere huic preparationi ex merito tuae actionis: etiam si per integrum annum te preparares et nihil aliud in mente haberes' Á Kempis, The Imitation of Christ; De imitatione Christi 582.

35 Á Kempis, The Imitation of Christ, book IV, ch. 9, 199. 'Quid possum agere pro peccatis meis nisi humiliter ea confitendo et lamentando; et tuam propitiationem incessanter deprecando?' Á Kempis, The Imitation of Christ; De imitatione Christi 575.

36 Wandel, Reading Catechisms 232, 263. 
Enchiridion taught: 'a person who has faith in these words, "given for you", and "shed for you for the forgiveness of sins", is really worthy and well prepared.37 Both the Genevan Catechism and the Heidelberg Catechism taught that pastors were to exclude the unworthy from Communion. ${ }^{38}$ Both taught that unworthiness was discernible. Both also taught self-examination as preparation for reception.

Each Reformation Church in its way, from the Catholic through the Lutheran to the Heidelberg theologians, struggled with the hidden unknowable in the Eucharist. For all but the Anabaptists, baptism was a sacrament administered in front of the entire congregation, a Christian public, to infants, whose inner person was not yet formed and did not inform the sacrament in any way. The Eucharist was utterly different. Even as it shared with baptism the same space, the communal space of the congregation, at its very centre was that towards which Paul had pointed: the inner person. Calvin and the Heidelberg theologians held the possibility that that inner person manifested her- or himself in the community, but Calvin in particular struggled with questions of 'Nicodemism' and deception: ${ }^{39}$ the potential for disjunction between visible behaviour and inner belief.

\section{4}

\section{Conclusion}

For all the Churches of the Reformation as well as for the medieval Church, the moment of Communion was always simultaneously shared and intensely personal. Shared were the zones of Communion, from the walls demarcating the space of worship through approaching the altar to the zone between bread and mouth, even as Churches differed as to whether any of the zones were sacred. Shared, too, were the cadences of worship, the movement of preparation from entering the church to reception, from the ancient and complex movement of the Mass to Calvin's intentionally simplified order of service.

For each Church the moment was also intensely personal. The Churches differed on what exactly the communicant received in his or her mouth, ${ }^{40}$ but they were agreed that receiving 'unworthily' posed potential damnation. They

37 Ibidem, 265, from Luther Martin, "The Small Catechism", ed. R. Kolb - T. Wengert, The Book of Concord: The Confessions of the Evangelical Lutheran Church (Minneapolis, MN: 2000) 363 .

38 Wandel, Reading Catechisms 270-273.

39 On Calvin and Nicodemites, see most recently Woo K.J., Nicodemism and the English Calvin, 1544-1584 (Leiden - Boston: 2019).

40 Wandel, The Eucharist in the Reformation. 
were agreed that the inner person was inseparable from what was received in Communion. 'Unworthiness', as the Imitatio Christi and its enormous popularity testify, points precisely to conundrum at the very centre of Communion: that the formal and public liturgy which surrounds the moment of reception does not and cannot ensure that Christ is really present, that the matter of the host remains the same for all present. 'Unworthiness' pointed precisely not only to the instability of the matter of the host, but also to the intimacy of the encounter between person and God, an intimacy that was, following Paul's warning, separate from the formal liturgy.

While priests and pastors could bring the full range of their authority to bear on the moment of Communion, preaching their Church's particular doctrine of the Eucharist, enjoining self-examination and open acknowledgement of ones' thoughts and belief, none could ensure that in the very moment of Communion, the matter the recipient received in her/his/their mouth would be constantly that which the Church taught it was, let alone what the Church taught it would be if a recipient had not prepared him- or herself properly. The moment when the sinning person received the consecrated host in her/ his/their mouth was radically intimate, utterly invisible to others. In that very moment, the communicant received the body of Christ, bread, or damnation, depending on what was inner to the person, not necessarily visible to others and in that way, not publicly knowable. Unique to each communicant, in the moment that the host crossed the lips of the open mouth, the threshold of each person, the great drama of grace or damnation occurred, hidden to all but God.

Was that moment then 'private'? The question of 'worthiness' leads to the inscrutability of each person beyond what any public might see - the essential unknowability of each individual. But 'worthiness' also presumes the presence of God, as knowing and judging in the very moment when public ritual meets intimate encounter: those red lips and differentiated hosts. That moment was then 'private' in the sense of 'private devotion', even as it occurred in spaces that were communal, but let me suggest that 'intimate' might be a better term, as it presumes two in zone of mouth and host, the individual communicant and God. 


\section{Bibliography}

Á Kempis Thomas, The Imitation of Christ, trans. L. Sherley-Price (Hammondsworth: 1952).

Á Kempis Thomas, The Imitation of Christ; De imitatione Christi, ed. P.A. Böer (Middleton, DE: 2014).

Bradshaw P.F., Rites of Ordination: Their History and Theology (Collegeville, MN: 2013).

Braun J., Der christliche Altar in seiner geschichtlichen Entwicklung, 2 vols. (Munich: 1924).

Bynum C.W., Holy Feast and Holy Fast: The Religious Significance of Food to Medieval Women (Berkeley, CA: 1987).

Bynum C.W., "Seeing and Seeing Beyond: The Mass of St. Gregory in the Fifteenth Century", in Hamburger J. - Bouché A.-M. (eds.), The Mind's Eye: Art and Theological Argument in the Middle Ages (Princeton, NJ: 2006) 208-240.

Durand William, Gvillelmi Dvranti Rationale Divinorvm Officiorvm I-IV, ed. A. Davril T. Thibodeau (Turnhout: 1995).

Durand William, William Durand: On the Clergy and Their Vestments, trans. T. Thibodeau (Chicago: 2010).

Gormans A. - Lentes T. (eds.), Das Bild der Erscheinung:Die Gregorsmesse im Mittelalter (Berlin: 2007).

Hoever H.H. (ed.), Saint Joseph Daily Missal (New York: 1950).

Jung J., The Gothic Screen: Space, Sculpture, and Community in the Cathedrals of France and Germany, ca. 1200-1400 (Cambridge - New York: 2013).

Jungmann J., Missarum Sollemnia: Eine genetische Erklärung der Römischen Messe, 2 vols. (Freiburg: 1962).

Kumler A. "Counterfeiting the Eucharist in Late Medieval Life and Art", in Melion W.S. - Pastan E. - Wandel L.P. (eds.), Quid est sacramentum? Visual Representation of Sacred Mysteries in Early Modern Europe, 1400-1700 (Leiden - Boston: 2019) 57-81.

Levy I.C. - Macy G. - Van Ausdall K. (eds.), A Companion to the Eucharist in the Middle Ages (Leiden - Boston: 2012).

Lipton S., Dark Mirror: The Medieval Origins of Anti-Jewish Iconography (New York: 2014).

Luther Martin, The Small Catechism, ed. R. Kolb - T. Wengert, The Book of Concord: The Confessions of the Evangelical Lutheran Church (Minneapolis, MN: 2000).

Meier E., Die Gregorsmesse: Funktion eines spätmittelalterlichen Bildtypus (Cologne: 2006).

Mellinkoff R., Outcasts: Signs of Otherness in Northern European Art of the Late Middle Ages, 2 vols. (Berkeley, CA: 1993). 
Miller M.C., Clothing the Clergy: Virtue and Power in Medieval Europe, c. 800-1200 (Ithaca - London: 2014).

Nickson T., Toledo Cathedral: Building Histories in Medieval Castile (University Park, PA: 2015).

Siebenhirter Hours [ca. 1470], Stockholm, Kungliga Biblioteket, MS A 225.

Spicer A. (ed.), Lutheran Churches in Early Modern Europe (Abingdon - New York: 2012).

Tanner N.P., S.J. (ed.), Decrees of the Ecumenical Councils, 2 vols. (London - Georgetown: 1990).

Van der Ploeg K., Art, Architecture, and Liturgy: Siena Cathedral in the Middle Ages (Groningen: 1993).

Wandel L.P. (ed.), A Companion to the Eucharist in the Reformation (Leiden - Boston: 2014).

Wandel L.P., The Eucharist in the Reformation: Incarnation and Liturgy (New York Cambridge: 2006).

Wandel L.P., Reading Catechisms, Teaching Religion (Leiden - Boston: 2016).

Wandel L.P., "Vestments in the Mass", in Melion W.S. - Pastan E. - Wandel L.P. (eds.), Quid est sacramentum? Visual Representation of Sacred Mysteries in Early Modern Europe, 1400-1700 (Leiden - Boston: 2019) 82-104.

Wandel L.P., Voracious Idols and Violent Hands: Iconoclasm in Reformation Zurich, Strasbourg, and Basel (Cambridge - New York: 1995).

Young K., The Drama of the Medieval Church (Oxford: 1933). 